\title{
Policy and financing - why is sea transport currently invisible in the search for a low carbon future for Pacific Island Countries?
}

\author{
Peter R. Nuttall ${ }^{1 *}$, Alison Newell ${ }^{1}$, Amelia Bola ${ }^{1}$, John Kaitu'u' ${ }^{1}$ and Biman Prasad ${ }^{2}$ \\ 1 Sustainable Sea Transport Research Programme, The University of the South Pacific, Suva, Fiji \\ ${ }^{2}$ School of Business, James Cook University, Townsville, QLD, Australia
}

Edited by:

Robin Margaret Warner, University of Wollongong, Australia

Reviewed by:

Mary Ann Palma-Robles, University

of Wollongong, Australia

Anne Marie Geraldine O'Hagan,

University College Cork, Ireland

\section{*Correspondence:}

Peter R. Nuttall, Sustainable Sea

Transport Research Programme,

Pacific Centre for Environment and

Sustainable Development,

University of the South Pacific,

Private Bag, Laucala Bay, Suva, Fiji

e-mail:peter.nuttall@usp.ac.fj
The role of financing and policy in research, development, trialing and introduction of renewable energy technologies in the Pacific maritime sector is considered. Key research and trials of renewable energy technologies for sea transport in the Pacific from the 1980 s and the critical role played by agencies such as the United Nations in leveraging support from funders such as the Asian Development Bank and European Union are reviewed. The lack of current policy on potential renewable energy technology use in sea transport at national, regional, and development agency levels is discussed with the Asian Development Bank used as a case study. The urgent need for such technology to be commercially trialed as a means of reducing the region's dependency on fossil fuels given the importance of sea transport to socio-economic development in the Pacific is outlined in light of the proportion of fossil fuel currently used by the maritime sector. The paper concludes that review of current funding strategies and policies to include both sea transport and the potential for use of renewable energy technologies in the maritime sector in the Pacific is a priority and current reliance on the private sector acting alone needs review.

Keywords: financing, policy, sea transport, Pacific, renewable energy, fossil fuel reduction

\section{INTRODUCTION}

This paper questions why maritime fuel use is currently excluded from most debate over reducing Pacific Island Countries (PIC) dependency on imported fossil fuels. It examines the efforts made in exploring renewable energy use for sea transport in the Pacific during the last oil crisis and finds that the results showed strong potential, were achievable with relatively minimal financial investment, and were only curtailed because of the global fall in oil prices (Asian Development Bank (ADB), 1985; Satchwell, 1985, 1986; Clayton, 1987). Despite heightened interest in renewable energy technology and its inclusion almost universally in national, regional, and donor strategies for electricity generation across the Pacific, the subject of low-carbon substitution for maritime fuel use is currently near invisible. We conclude that this is irrational and explore the reasons for such exclusion.

The international shipping industry is engaged in an unprecedented search for greater efficiency in fuel consumption and emission. Global interest in low carbon technologies for shipping is growing, but solutions at the small-scale level appropriate to the domestic needs of PICs have yet to be seriously explored. The main options to reduce fuel use and emissions can be grouped into four categories-alternative fuels, operational efficiencies, technology advances, and renewable energies. The unique characteristics of the Pacific mean the options available to the global theater are not necessarily the most accessible or appropriate. This is due to the characteristics of local demand; the Pacific merchant fleet (blue water but small and old, higher proportion of petrol to diesel); a lack of access to financing for new technologies; and the prohibitive cost and practicality of establishing extensive bunkering and support infrastructure for alternative fuels. There is considerable scope for operational efficiency improvements for both the current vessels and related infrastructure (port design and options, feeder transport networks, etc.) and this will be true regardless of the fuel type used by shipping. These same factors likely make renewable energy technologies, such as wind and solar, more appropriate for a range of Pacific applications than at a global scale. Biofuels, from coconut oil and biomethanes, have strong potential, again especially for more isolated communities with high biomass availability.

The critical importance of sea transport to the region and its interrelationship with all levels of socio-economic development is well recognized and the dire situation concerning domestic shipping has been identified and well-documented over time (see in particular ADB, 2007; Couper, 2009; United Nations Economic and Social Commission for Asia and the Pacific (UNESCAP), 2010; Secretariat for the Pacific Community (SPC), 2011; Nuttall, 2013). Alternatives to current fossil fuel-powered sea transport is a "missing link" in current PIC policies and approaches to renewable energy and efforts to reduce reliance on imported fuels (Nuttall et al., 2014). Renewable energy-assisted shipping, while often using known and proven wind, solar, and biofuel 
technology, is an emergent option for sea transport globally. Research, analysis, and development of commercial models, especially for Small Island Developing States (SIDS), lags far behind research and promotion of other renewable energy applications especially for electricity generation. However, past and current research is clear that such technology offers strong potential to both reduce PIC reliance on imported fossil fuel and revolutionize PIC shipping (Nuttall, 2012, 2013; Nuttall et al., 2014). Current domestic shipping, although often financially marginal and employing aged asset, maintains sufficient control of the industry to continue to use fossil fuels because there is a lack of sufficient incentive to adopt new technologies and a lack of commercially demonstrated alternatives (Prasad et al., 2013). Ever increasing costs of fuel and operations are either passed to consumers or borne by government subsidies. Our research suggests that renewable energy shipping offers benefits across multiple well-beings (economic, environment, social, cultural) and at local, provincial and intra-regional levels. It offers a potential future where fleets of smaller but more sustainable new ships can replace current single, aged, large vessel operations. Realization of this requires economic analysis and practical demonstration of commercially viable models if up-take on any scale is to be achieved (Nuttall et al., 2014).

Renewable energy use for sea transport has almost no profile currently in policy and strategic instruments at local, regional, or development agency levels and is invisible in funding initiatives. For example, the recent New Zealand/European Union (EU) hosted Pacific Energy Summit in Auckland in March 2013 resulted in NZ\$635 million ${ }^{1}$ of pledged support to fast-track renewable energy uptake and reduce regional reliance on diesel imports. However, not a single project is targeted at sea transport and conference organizers reported that sustainable sea transport has not been identified as a key priority for implementation of the Pacific Energy Summit outcomes. At a 2013 high-level meeting $^{2}$ hosted by UNESCAP, the International Maritime Organization (IMO), SPC and the Pacific Islands Forum Secretariat (PIFS) on the regional shipping situation most country delegates reported a chronic and increasingly unaffordable situation with domestic shipping. However, the need for sustainable shipping was highlighted by several presenters at the August 2013 Pacific Island Development Forum (PIDF) and sustainable sea transport has been included in the PIDF Outcomes Statement. More recently Transport and Energy Ministers for the region acknowledged the need "to investigate alternative sources of energy to support the shipping industry" (SPC, 2014: 3). However, to date, this has yet to transform into concrete policy or donor commitment.

Despite most PICs setting ambitious targets for transitioning from fossil fuels to renewable alternatives for electricity generation, to date only the Marshall Islands has set a target for reducing transport dependency (20\% reduction in fuel used by

\footnotetext{
${ }_{1}^{1}$ http://www.beehive.govt.nz/release/635-million-energy-efficient-pacific (Accessed 31 March, 2014).

${ }^{2}$ High-level Meeting on Strengthening Inter-island Shipping and Logistics in the Pacific Island Countries, cohosted by ESCAP, IMO, and SPC, 23-25 July 2013, Suva, Fiji.
}

2020) (Majuro Declaration, 2013) ${ }^{3}$. A target of $25 \%$ reduction by 2032 was set under the SIDS Dock initiative of which 13 PICs are signatories. Modeling this against 2012 baseline assumptions of around 250,000 l of fuel used by the maritime sector in the region and using a nominal 3\% annual growth in transport would mean PICs will need to substitute a similar amount of fuel to that currently used by 2032 if this target is to be met (see Figure 1). Given the current inaction, this seems highly unrealistic without substantial commitment of resources and policy priority.

The need for sustainable sea transport in the Pacific is vital for its plans for regional cooperation and integration. As pointed out by UNESCAP (2012, p. xxiii) "economic integration depends critically on the development of seamless connectivity between countries." More sustainable and affordable shipping services are not only expected to boost connectivity between countries but within countries as well. Air transport is likely to remain underdeveloped in the Pacific and even if it improves it is unlikely to provide an effective substitution for sea transport. The future of PIC economies and potential for trade will depend on effective sea transport for the foreseeable future.

\section{PACIFIC DEPENDENCY ON FOSSIL FUEL}

PICs are precariously dependent on imported fossil fuels raising critical issues of fuel price and security of supply (Woodruff, 2007). The Pacific is the most dependent region in the world on imported fuels at $95 \%$ dependency (99\% if PNG and Fiji are excluded). Imported petroleum products account for an average of $40 \%$ of PICs' GDP and fuel imports average $14-20 \%$ of foreign exchange earnings (AusAID, 2008). Such reliance represents a major drain on economies, a barrier to development, and a source of vulnerability (Jafar, 2000) and has seen PICs suffer the full impact of the recent global fuel crisis (AusAID, 2008). Fossil fuel dependency is recognized as having a crippling effect on national budgets and revenues and impacts on key productive

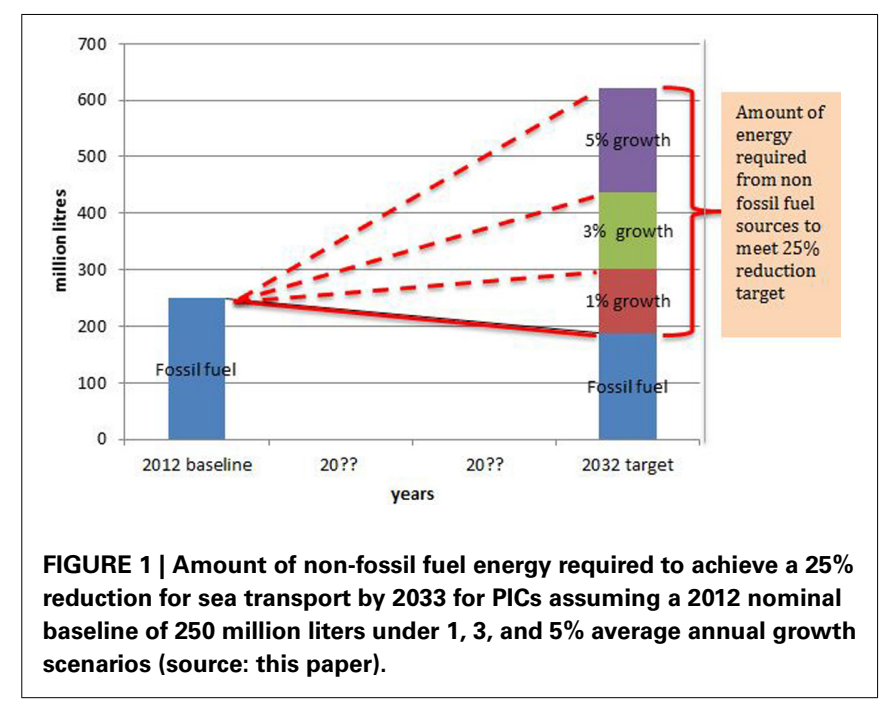

\footnotetext{
${ }^{3}$ Majuro Declaration for Climate Leadership. Pacific Islands Forum Leaders Statement, 5 September 2013.
} 
sectors in the region such as fisheries, agriculture, and tourism (UNESCAP, 2010).

When considered by sector, transport constitutes the largest user of fuel. The International Renewable Energy Agency (IRENA) considers that on average transportation accounts for $75 \%$ of oil consumption regionally while electricity generation accounts for more than 20\% (IRENA, 2012). SPC considers transport to use $70 \%$ of region fuel imports (SPC, 2011). Mayhew (2011) however states transport uses $48 \%$ as a regional average. The lack of reliable data makes it difficult to verify these figures, but what is clear is that transport is the single largest user of imported fossil fuel in the region and a significantly greater user than electricity generation. There is also no reliable regional data to calculate what percentage of this is attributable to sea transport as a sub-sector but Mayhew (2011) considers it could be as high as $75 \%$ of all fuel used for some PICs. In extreme scenarios, such as Tokelau, sea transport could account for up to $90 \%$ of the total energy budget (Nuttall, 2013).

There is a dearth of reliable data for the domestic maritime sector from which to make firmer informed conclusions and this factor is a critical inhibitor to ongoing analysis and research. There has been almost no work done at local community level in particular, however a recent study of one remote island village in Fiji found sea transport constituted the largest single user (54\%) of the village's fossil fuel footprint (Newell and Bola, in press). We contend this scenario is not unrepresentative and current work at the University of the South Pacific (USP) looks to provide a template for replicating this research in other Fiji locations (Prasad et al., 2013). We suggest fuel conservatively accounts for $40-60 \%$ of the region's domestic commercial shipping operators' overheads and for many operators it is likely a much higher percentage of total operating costs. Such costs make reliable delivery of services to island communities difficult as many routes are either highly marginal or economically unviable, a situation that places enormous strain on government shipping capacity and increasingly high costs to subsidize such routes as imported fuel costs rise.

Using data derived from the draft 2013 National Energy Policy for Fiji as an example we calculated overall fuel costs by sector for 2011. Fiji imported 707 million liters of fuel at an overall value of FJ 1.17 billion (US $\$ 640$ million), of which approximately 50\% was retained in-country and the remainder transhipped to other PICs. Of the $\sim \mathrm{FJ} \$ 585$ million used nationally, $\sim \mathrm{FJ} \$ 100$ million is recorded as being used for commercial electricity generation. Transport collectively used $64 \%$ of the total, broken down by subsector to land $(16 \%)$, air $(26 \%)$, and marine $(22 \%)^{4}$. This leaves $17 \%$ of other use, a proportion of which will include noncommercial off-grid electricity generation and fuel for household lighting and cooking. Sea transport appears on this evidence as a single national user roughly equivalent to all fossil fuel used for electricity generation. As such it would appear a logical target for demand reduction or substitution effort. The response to this rationale for prioritizing transport as the dominant fuel user is that electricity generation represents the "low hanging

${ }^{4}$ The data in the draft National Energy Policy is sourced from Fiji Department of Statistics. fruit" for donor and government effort and there are few options for sea transport (Mayhew, 2011). However, there is little hard analysis to show that renewable energy electricity projects are as cost effective or generate greater long-term gains than a similar investment in shipping would achieve and so this must be concluded on available evidence to be nothing more than an untested assumption.

\section{SEA TRANSPORT IS CURRENTLY INVISIBLE IN THE POLICY SPACE}

Sea transport is a central need of many Oceanic communities and at all levels. Politically, transport is a priority area for Pacific Forum Leaders under the Pacific Plan, the overarching regional blueprint, and its importance as a facilitator of economic growth is recognized. "Continued focus through regional and sub-regional approaches to improve shipping and aviation services, aviation liberalization, safety, and security as well as the supporting infrastructure remains essential for all Pacific SIDS" (UNESCAP, 2010, p. 59).

In 2004 Forum Leaders endorsed the Forum Principles on Regional Transport Services (FPRTS) in recognition that the provision and maintenance of regular, reliable, and competitive air and shipping services is crucial to Pacific SIDS. They recognized changes in the transport sector, such as increasingly competitive markets and new international safety and security requirements, as well as the limited technical capacity in-country for most PICs. The FPRTS contains six principles promoting good governance, transparency, and accountability, and aims to serve as a guideline to Pacific SIDS in their pursuit for greater service delivery to improve the efficiency, effectiveness, and sustainability of both air and shipping services (UNESCAP, 2010, p. 59).

At their ministerial meeting in Tonga in May 2009 the Pacific Ministers of Transport further recognized that internationally compliant transport services are imperative for economic growth and human development (SPC, 2011, p. 1) and instructed SPC to produce the resultant Framework for Action on Transport Services 2011-2020 (FATS). Although the political leadership being shown in marine transport regionally, on paper at least, is commendable, especially in light of the resources available for implementation, it still has some way to go. The 2010 UNESCAP report highlighted the regional commitment to developing a Green Growth Strategy for sustainable production and consumption and the sub-regional project on environmentally sustainable transportation in the Pacific Islands for land transportation (UNESCAP, 2010, p. 61). However, renewable energy technologies for marine transport have not thus far been included in SPC's FATS or their 2011 Framework for Action on Energy Security in the Pacific although, as discussed above, it has been identified by the PIC Ministers as an issue.

There are now a wide range of climate change mitigation and adaptation strategies from governments, regional agencies, and donor partners in the Pacific. Sea transport is not mentioned in any, bar the Marshall Islands, except in passing within a broad context of transport or infrastructure. Despite the fact that almost any adaptation strategy that seeks to enhance local resilience or increase adaptive capacity of island or coastal communities is going to be affected by the effectiveness, availability, and cost of 
sea transport, the subject of providing more sustainable options has yet to be recognized in any of them. There are few examples of adaptation-related projects (or any aid, development, or conservation project for that matter) in any of the current agency strategies that do not include some aspect of sea transport. For many, sea transport costs are significant budget lines. There is a fatalistic nihilism and contradiction inherent in the suggestion that adding to global emissions is a necessary evil to implement programs that will in turn allow communities to avoid or resist the worst consequences of increasing emissions.

In recent funding rounds AusAID have considered transport in a climate change-related context to be "mitigation" and therefore largely unworthy of funding in the Pacific. USAid (2010) and $\mathrm{ADB}$ (see case study below) both see adaptation measures as concerning only future-proofing existing and future transportrelated infrastructure (specifically roads, ports, and airports). As processes for all such agencies to prioritize climate changerelated funding are now largely framed, the potential for accessing resourcing for additional areas of activity, such as sea transport, is severely reduced.

\section{ASIAN DEVELOPMENT BANK POLICY: A CASE EXAMPLE}

As an in-depth example, we examined ADB's recent transport initiatives. ADB has long been the principal loan source for infrastructure in the Pacific. Its Asia-Pacific region encompasses a multitude of diverse countries with a catchment of 1.8 billion people (ADB, 2010a), many with differing priorities and objectives to Oceania. Transport is one of the main sectors ADB supports, comprising 27\% of all projected loans in 2010-2012, mainly for roads and railways. Water transport attracts less than $1 \%$ of this US\$ 3.4 billion (ADB, 2010b).

During 2008/2009, ADB developed the Climate Change Implementation Plan for the Pacific (CCIP) to address PICidentified adaptation and mitigation needs "in close consultation with Pacific Island country leaders.” The key recommendation of the CCIP is to mainstream climate change issues into ADB operations in the region by ensuring that (1) climate-related risks and vulnerabilities are adequately reflected in the country partnership strategies of PICs; (2) all projects in the ADB pipeline are screened in relation to climate-related risks, and (3) all infrastructure and other relevant projects are climate-proofed. The Pacific Climate Change Program (PCCP) is the main vehicle for implementing the CCIP.

The principal objective of the PCCP is to ensure the continued economic growth of PICs in the face of global climate change, by reducing their vulnerability to its risks and impacts and comprises a three-pronged strategy, the first two of which are: (1) immediate attention to fast tracking and scaling up climate change adaptation and mitigation investment; and (2) promoting renewable energy through new technology, and research and development. Both might be considered inclusive of renewable energy sea transport. But when one drills further into the PCCP, transport is a subset of "energy," the last of six priority sectors. Under this heading ADB will consider investment in transport, "consisting primarily of (1) climate proofing of roads, ports, and airports; (2) reduction of GHG emissions from transport through the use of clean energy in vehicles; and (3) limited investments in alternative and cleaner fuels (for example, biofuels development)" (ADB, 2010a). Sea transport per se is never mentioned; in fact the use of the descriptive "vehicles" does not strictly include "vessels" as a subset and so could be read to exclude sea transport. At best it has not been considered. A case could be made to ADB that it would qualify under "limited investments in alternative/cleaner fuels" but this is a long shot and is again couched in terms of mitigation, i.e., reduction of GHG emissions, not as an alternative to fuel dependency or adaptation measures. In a competitive funding environment with multiple demands and priorities, sustainable sea transport is by default placed in a heavily penalized position under the PCCP.

In 2007, prior to producing the PCCP, ADB released a regional overview on Pacific shipping. It found that international level shipping is reasonably well catered for but that there are large issues to resolve at domestic and local levels, complicated by the region's unique maritime profile. The concept of low-carbon or renewable energy shipping is not considered. There is as much or more attention given to shore-side infrastructure and administration as to ships and shipping. No solutions are suggested for domestic shipping, except to recommend greater privatization of services (ADB, 2007). The key role played by ADB in this sector in the last oil crisis, as discussed below, is not referred to.

After release of the PCCP, ADB produced its Asia-Pacific region Sustainable Transport Initiative (STI) in 2010. In the next decade ADB estimate the countries of Asia and the Pacific will need to invest US\$8 trillion in infrastructure by 2020 , with much of this being for transport. The STI will guide ADB transport investment for the foreseeable future and is a cross-sector strategy spread across economic growth, sustainable development, and climate change. The STI defines a sustainable transport system as one that is accessible, safe, environment-friendly, and affordable and one that incorporates multiple overlapping dimensions of sustainability.

While the situation varies from country to country, ADB's support for transport modes other than roads and railways has been very limited historically. Urban transport is the major future focus of the STI. It is acknowledged that air and sea transport and ports have grown rapidly in the region. However, in the early 1990s, ADB largely phased out its support claiming the private sector was already performing effectively in these areas. $\mathrm{ADB}$ did continue to support a small number of members, including PICs "where aviation and ocean transport have a unique role due to limitations in land transport, generally linked to factors such as geography and low population density" (ADB, 2010a, p. 8). Overall, bicycles and pedestrian infrastructure get more attention than sea transport in the STI.

\section{LESSONS FROM THE LAST OIL CRISIS}

What is the evidence that renewable solutions may be available and that they would deliver cost effective savings? A small number of critical experiments occurred during the 1973-1986 oil crisis (Nuttall, 2013; Nuttall et al., 2014). They are important to understand because they clearly demonstrated savings in fuel and costs are available at reasonable price, but also because of the process that evolved following the delay in investing in research and trialing at the outset of the crisis. UN agencies [UNESCAP, 
UN Development Assistance Team (UNDAT), UN Conference on Trade and Development (UNCTAD), UN Development Programme (UNDP), and Food and Agriculture Organization $(\mathrm{FAO})]$ and $\mathrm{ADB}$ played catalytic roles. We conclude that a similar pattern is discernible today and that the same agencies are well placed to repeat their earlier role with the added advantage that the research undertaken in the 1980s can now be used as an immediate starting point. Furthermore, deeper issues over the long-term financing of domestic shipping in the Pacific that were apparent in the 1980s were not addressed at that time due to the relatively short-term nature of the event and we suggest these should now be reconsidered given that the current crisis is predicted only to escalate over time.

Globally a range of work was undertaken on maritime innovation in the last oil crisis including the "Efficient Ships" program in the UK which concentrated on hull and propulsion designs for conventional ships, a German-funded sail cargo ship program in Indonesia, and the Wind Ship Corporation's comprehensive assessment of wind-powered rigs in the US. Other important projects were initiated in Japan, France, Germany, and Scandinavia. In the Pacific we identified five significant projects (summarized in Table 1) that provide direct relevance and signposts for the current scenario: the UNDP/FAO work on artisanal fishing vessels; the UN agency-led needs assessment and vessel design for the Ha'apai Group, Tonga; the ADB-funded retrofit experiments in Fiji; an EU-funded build of a sail auxiliary vessel in the Lau Group, Fiji; and the fixed-wing sail-assist oil tanker/bulk carrier program in Japan. In essence, experiments in Fiji with sail auxiliary rigs on cargo/passenger vessels in that period mirrored Japanese and Indonesian findings that such technology could cut fuel use by up to $30 \%$. Related work by Save the Children in Tuvalu and Kiribati and by FAO/UNDP across the region provided technology solutions for small-scale transport and artisanal fishing. The Tongan and Lauan-focused research in 1982-1984 identified strong potential for economically viable catamaran and small freighter combinations, findings that mirror recent research in Fiji (Nuttall, 2012, 2013; Nuttall et al., 2014).

Commencing in 1982 UNDAT, UNCTAD, and UNESCAP combined resources to undertake a series of studies in the Ha'apai Group, Tonga. The principal objective was to investigate an energy-efficient government-operated vessel. Having mapped the need and the options available (Eyre and Philp, 1982; Kami and Dillon, 1982), the project moved toward implementation in 1983. Securing funding proved difficult with donors citing "insufficient insight into the financial and technical feasibility of the project" (Palmer and Corten, 1985, pp. 133-134). Yet without funding a formal feasibility study was not possible. The vicious circle was broken by UNESCAP and ADB providing the resources to recruit

Table 1 | Pacific Island based programs for renewable energy shipping during the 1980s oil crisis (sources: Brown, 1982; ADB, 1985; Satchwell, 1985, 1986; FAO, 1987; Nuttall, 2013).

\begin{tabular}{|c|c|c|c|c|}
\hline Project & Description & Outputs & Agencies & Comments \\
\hline Fiji soft sail retrofit & $\begin{array}{l}\text { Auxiliary rig designed and } \\
\text { retrofitted to two government } \\
\text { vessels of } \sim 300 t \text {. Rigs built and } \\
\text { installed in-country }\end{array}$ & $\begin{array}{l}\text { Fuel savings } 23-30 \% \text {, but also } \\
30 \% \text { engine/prop wear reduction, } \\
\text { greater stability, increased } \\
\text { passage times. IRR on best route } \\
=127 \% \text {, average route }=33 \%\end{array}$ & $\begin{array}{l}\text { ADB, } \\
\text { Southampton } \\
\text { University, } \\
\text { McAllister Elliot }\end{array}$ & $\begin{array}{l}\text { Southampton University collated } \\
\text { historical wind data for all Fiji } \\
\text { routes and produced fuel saving } \\
\text { ratios for all routes }\end{array}$ \\
\hline $\begin{array}{l}\text { Lau } \\
\text { passenger/cargo } \\
\text { vessel }\end{array}$ & $\begin{array}{l}\text { 50-ton sail trading vessel, built on } \\
\text { Kabara by local builders } \\
\text { (1984-1987). First of } 3 \text { vessels to } \\
\text { service Lau and Lomaiviti groups }\end{array}$ & $\begin{array}{l}\text { Tai Kabara became the main } \\
\text { vessel operating on the Sth Lau } \\
\text { route until she was scuttled in } \\
2006 \text {. Used local materials } \\
\text { wherever possible }\end{array}$ & European Union & $\begin{array}{l}\text { Construction of the other two } \\
\text { ships was canceled when the oil } \\
\text { crisis abated }\end{array}$ \\
\hline $\begin{array}{l}\text { Ha'apai energy } \\
\text { efficient freighter }\end{array}$ & $\begin{array}{l}\text { Needs assessment led to } \\
\text { commissioning vessel build plans }\end{array}$ & $\begin{array}{l}\text { Needs assessment, transport } \\
\text { census and full build plans for a } \\
\text { 100-ton energy efficient freighter }\end{array}$ & $\begin{array}{l}\text { UNESCAP, } \\
\text { UNCTAD, UNDP, } \\
\text { ADB }\end{array}$ & $\begin{array}{l}\text { Vessel never constructed due to } \\
\text { end of crisis. Similar needs } \\
\text { assumed today }\end{array}$ \\
\hline $\begin{array}{l}\text { Save the Children } \\
\text { Fund/Jim Brown }\end{array}$ & $\begin{array}{l}\text { Save the Children Fund Tuvalu } \\
\text { employed catamaran designer } \\
\text { Brown to develop locally built } \\
\text { boats for Tuvalu/Kiribati }\end{array}$ & $\begin{array}{l}\text { A range of designs and processes } \\
\text { for locally built/operated } \\
\text { catamarans for artisanal and } \\
\text { commercial fishing and local and } \\
\text { inter-island transport. Training of } \\
\text { local shipwrights. Local materials } \\
\text { favored }\end{array}$ & SCF & $\begin{array}{l}\text { This project closely associated } \\
\text { with the FAO/UNDP project. Local } \\
\text { build/materials used wherever } \\
\text { possible. Fuel savings of up to } \\
60 \%\end{array}$ \\
\hline FAO/UNDP & $\begin{array}{l}\text { Multi-county fisheries programme } \\
\text { to develop RE } \\
\text { artisanal/commercial vessels for } \\
\text { local community benefit }\end{array}$ & $\begin{array}{l}\text { A portfolio of } 10 \text { designs from } \\
\text { single dugouts to } 11 \mathrm{~m} \text { trimarans. } \\
350 \text { vessels built in } 8 \text { countries. } \\
\text { Demonstrated need for vessels to } \\
\text { be affordable and locally } \\
\text { appropriate }\end{array}$ & FAO, UNDP & $\begin{array}{l}\text { Uptake ceased with end of } \\
\text { project and falling fuel prices. } \\
\text { Communities with "living } \\
\text { tradition" of sail had greatest } \\
\text { uptake }\end{array}$ \\
\hline
\end{tabular}




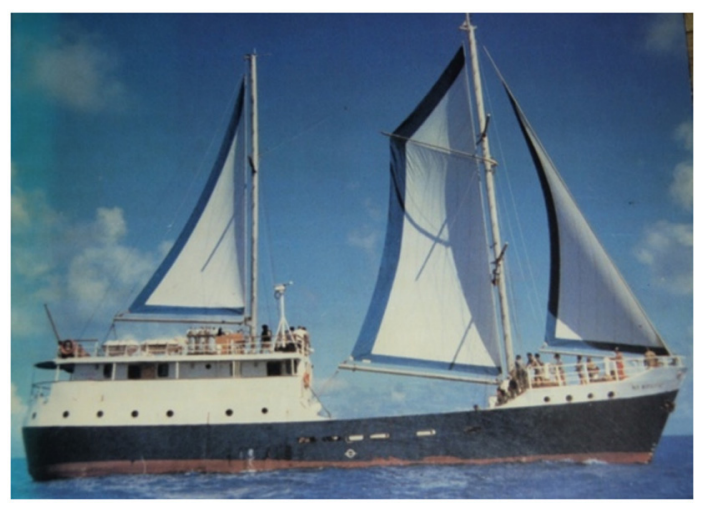

FIGURE 2 | Na Mataisau, Fiji, 1984 (source: ADB, 1985).

prominent UK naval engineers MacAlister, Elliott and Partners to work with local expertise to undertake the necessary evaluations and designs. It is assumed the sharp fall in oil prices after 1985 was the cause of no further development of this project. While we have the designs, the ship was never built.

Building on the Tongan research, a Fijian experiment overseen by Southampton University and funded by ADB saw auxiliary sail rigs designed and installed by the same engineering and design team for the Fijian Government fleet of cargo/passenger vessels (see Figure 2). Two ships were retrofitted and extensively trialed. Each employed a novel standing wishbone construction on the mainsail to give a quadrilateral sail that could be furled on luff spars.

The first ship was the 6-year-old $\mathrm{Na}$ Mataisau, a 274 gross ton passenger/cargo vessel with a single diesel engine. Conversion was carried out at a Fijian shipyard and completed in September 1984, whereupon the ship operated normal schedules with a continuous log kept to record performance data. Good performance was obtained in both sailing and motor-sailing modes with substantial speed enhancement in the latter (Clayton, 1987). Monitoring of the experiment was undertaken by Southampton University and the project reports (Satchwell, 1985) list an impressive range of savings and benefits, well in excess of those projected at the start of the experiment. Contrary to predictions the vessel performed exceptionally well, realizing none of the initial concerns over ultimate stability and leeward, and resulting in $23 \%$ overall fuel savings plus multiple benefits in terms of increased stability, greater passenger comfort, and greatly reduced engine wear. Much greater fuel savings could have been achieved if a feathering propeller had been fitted. The Investment Rate of Return on the US\$ 40,000 cost of the retrofit was calculated at an impressive $123 \%$ on the most favorable routes and $30 \%$ on average routes (Satchwell, 1985).

Unfortunately the vessel was lost after dragging its anchors on Moala reef in a developing cyclone in early 1985 but not before she was able to escape under sail alone after the engines failed and thus save the life of the Fijian Prime Minister, on-board at the time. The rig of $\mathrm{Na}$ Mataisau was rescued and subsequently installed on a larger ship, the Cagidonu. This retrofit was completed in December 1985 and showed average fuel savings of $20-25 \%$ on its inter-island schedules (Clayton, 1987). In his project report assessing the sailing performance Satchwell (1986) recorded savings of $37 \%$ with all sails and $21 \%$ with mizzen and jib only. The 1986 fall in world oil prices to near record lows did not justify the extension of the program and a return to cheap and plentiful fuel saw the end of these experiments.

Resulting from the UN-sponsored study in Tonga and a second study of the southern Lau group, Fiji, the European Union funded the construction of a sail-powered and locally built 50-ton trader for Kabara Island. The Tai Kabara was built literally on the beach at Naikeleyaga village by the mataisau (hereditary Fijian shipwrights) between 1984 and 1987. Although only one vessel was constructed, the initial proposal was for an inter-connected fleet of three vessels servicing the Lau and Lomaiviti groups (Nuttall, 2013). She was described to us by the builders as a ketch-rigged vessel of classic carvel plank on frame construction with a full keel, secondary bilge keels, or runners and cut away forefoot to allow for beach landing (Nuttall et al., 2014). The vessel operated successfully as an island-owned and operated trading vessel through the Lau group for the next two decades, surviving two cyclones and several beachings, before being scuttled in Suva harbor in 2008 (Nuttall, 2013).

Also in this period Save the Children Fund, in Tuvalu, and FAO/UNDP initiated practical research into using either pure sail or sail-assisted vessels for artisanal and small-scale commercial fishing and local transport. Renowned naval architect Øvid Gulbransen and the American catamaran designer Jim Brown produced a variety of vessel designs from one-person dugouts to large catamarans and trimarans (Brown, 1982; FAO, 1987). Under the FAO/UNDP program some 300 artisanal fishing boats of varying sizes from 4 to $11 \mathrm{~m}$ were distributed in various Pacific countries. Again, the end of the oil crisis coinciding with the end of the project funding and impetus saw this research largely curtailed.

The designs that resulted from this period would appear to have as much applicability now as they did then. The key lessons for us today from that research include that vessels must be appropriate to local conditions, affordable for local communities and/or governments and must be accessible. There is little point in designing and building high technology ships from outside the region and simply delivering them to local users (Savins, 2012). The issue is far wider than just introducing new technology. A whole of industry approach is needed including training local builders to construct and maintain vessels, training crews (including management and operational crews as well as sailors), and considering the role of secondary industry players, such as insurance companies and industry regulators. A collaborative approach that includes all relevant stakeholders from the outset is desirable. This includes government regulatory authorities, local communities, the existing shipping industry, and researchers to monitor the effectiveness of the projects. Simply showing up with a new boat and expecting all the necessary partners to fall into line is naïve, unrealistic, and counter-productive. Commercially-viable models are needed and must be proven in a full commercial operating environment. Alternatives to conventional shipping must demonstrate that they are economically viable if they are to be accepted at any scale. You might have the 
most environmentally-friendly vessel in the world but it is not going to succeed unless it can demonstrate that it is commercially competitive (Nuttall, 2013).

If the objective is to use sail technology then heritage is important. Those cultures that still maintain a living tradition of sail are far more likely to embrace new generation vessels than those who are two, three, or more generations removed (FAO, 1987). This means an uphill battle for most PICs today where, despite millennia of successful seafaring heritage, traditional sailing knowledge, and daily use is now restricted to a few small isolated pockets.

In the Japanese experiments, the initiative was taken by the private sector and again proved noteworthy. The Japan Marine Machinery Development Association (JAMDA) and Nippon Kokan KK (NKK) designed, built and operated a series of airfoilrigged ships between 1980 and 1988. The rig designs follow the same basic geometry in which a central mast supports a vertical rectangular steel framework with horizontal airfoil shaped ribs (Clayton, 1987). The first ship was a 1600 deadweight ton (dwt) tanker, the Shin Aitoku Maru. In 1984 two larger ships put to sea, the 31,000 dwt bulk carrier Aqua City and the 26,000 dwt Usuki Pioneer. The reported results were impressive with overall fuel savings of around 25-30\%, increased passage speeds, increased stability, and greatly reduced engine wear. Contrary to initial concerns, the sail-fitted vessels were able to safely maintain course in typhoon conditions where non-sail fitted sister vessels had to heave to UNESCAP (1984). However, plummeting oil prices meant the IRR on the technology was uneconomic, especially given the cost and limitations of the computer technology employed at the time, and the experiment was discontinued.

In addition to proving the ability to save fuel and costs without loss of performance, a secondary critical lesson of relevance to the current situation comes from the process of initiating and financing the research. The 1970s oil crisis had a clearly defined starting point: the tensions in the Middle Eastern oil fields and the 1973 Israeli-Arab war. As can be seen in Figure 3 where oil prices are mapped from 1966 to 2010 in 2010 US dollars, oil prices peaked in 1981 and then fell to almost pre-crisis levels by 1986 .

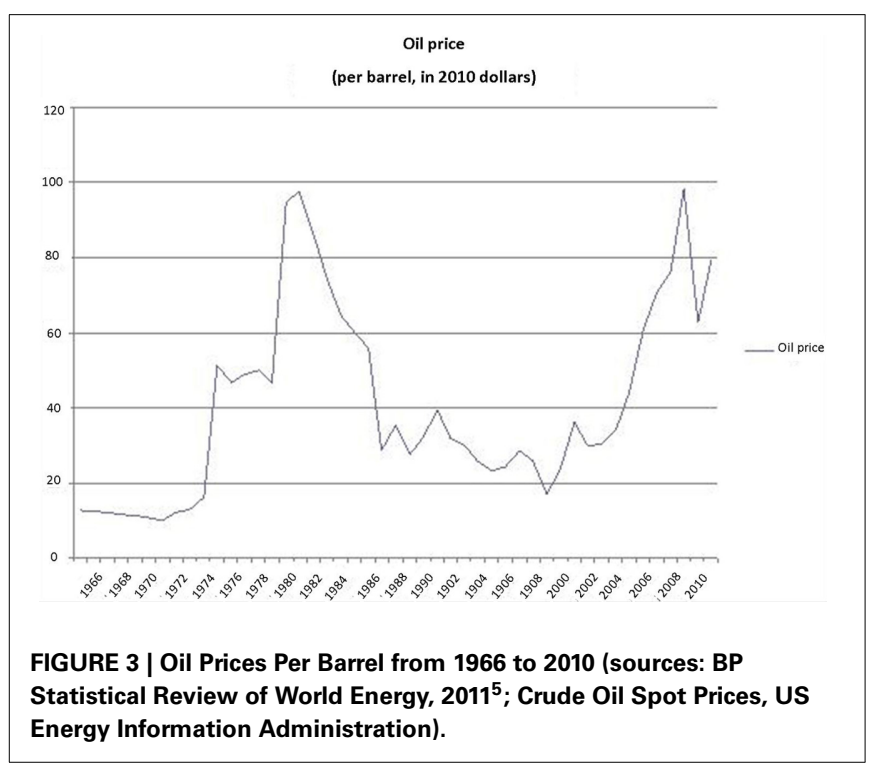

Prices then stayed relatively low until the start of the new century, peaking sharply in the global economic crisis that began in 2006. Today they are again over US\$ 100 a barrel. There is no expectation prices will fall dramatically in the future and almost all consensus is that oil will become increasingly expensive. For marine fuel there is the added constraint that IMO-led initiatives will result in greatly increased costs for developing world shipping. Nuttall (2013) calculated previously that IMO regulations on shipping emissions (MARPOL Annex VI) will incur significant penalties for operational costs because of increasing fuel prices, higher costs for cleaner fuel, and dramatically increased regulatory compliance cost. Adoption of renewable energy options could see this situation reversed with the potential added bonus of carbon credit trading returning subsidies as opposed to an endless cycle of ever increasing costs. Projected savings need to be assessed in terms of primary (e.g., direct fuel cost savings) and secondary (e.g., increased economic opportunity for direct inter-island and inter-regional trade).

As the rapid escalation in price and related concerns over security of oil supply began to bite in the 1970s, numerous measures were implemented world-wide to conserve fuel use. Such measures today are even more urgent with the increasing pressure and awareness of the growing crisis in global warming and the result is the current flurry of activity aimed at reducing the Pacific's fuel dependency and conversion to low carbon and renewable energy sources. Innovation in shipping however lagged, then as now. It took some 8 years from the time the 1973 oil price rise began until public sector financing was committed to action in the Pacific. FAO mobilized its artisanal fishing program in the Pacific, largely off the back of a relatively small project initiated by Save the Children Fund in Tuvalu (Brown, 1982; FAO, 1987). By the end of the crisis this involved a variety of designs built and distributed in eight Pacific countries. The work with commercial domestic sea transport in Fiji and Tonga was the direct result of one small but catalytic study funded by UNDAT. Sufficient funds to move to practical trials were not committed until leveraged from ADB by UNESCAP and other UN agencies in 1983 and the program was curtailed by the end of 1986 . However, the results achieved in that period were significant.

It is now 8 years since oil prices peaked in 2006 and they have risen past this record now. As discussed above, sustainable sea transport for PICs has made little visible imprint in either the policy or the donor project space today. The current small program initiated by USP, supported by a growing network of local and international actors, is thus far a solitary attempt at a long-term research-based program. The Sustainable Sea Transport Talanoa $(\text { SSTT })^{6}$ hosted in 2012 by USP on behalf of that network was the first such international conference on this subject in the region since a similar event organized by ADB in Manila in 1985 (ADB, 1985). The SSTT was highly successful in bringing together the cutting edge of international research and focusing them on the issue at a Pacific region and island state level.

\footnotetext{
${ }_{5}$ http://www.bp.com/content/dam/bp/pdf/Statistical-Review-2012/statistical_ review_of_world_energy_2012.pdf

${ }^{6}$ See https://www.usp.ac.fj/index.php?id=12456 for the SSTT 2012 programme, Outcomes Record, presentations, et cetera.
} 
It is now imperative that policy and donor response follows with concrete action. The situation today mirrors many of the characteristics of the previous period. Given that the current crisis is unlikely to end as oil prices are unlikely to reduce in the foreseeable future, and the need to reduce GHG emissions make a low carbon future even more desirable, it is essential that these lessons are now taken onboard as the basis for new initiatives to employ renewable energy solutions. The research from the 1980s provides a well-marked starting point for a fresh phase of work; it is not a case of having to reinvent the wheel. In particular the catalytic role of UN agency/ADB-funded initiatives is highlighted. Recent research (Rojon, 2013) indicates the failure to afford priority to the maritime shipping sector is not restricted to the Pacific but has been a consistent feature of past energy crisis's internationally since at least the 1920s. All research to date indicates strong potential for multiple benefits at all levels of the current Pacific sea transport industry, especially on domestic and inter-state routes, including reduced operating costs, reduced government subsidies, fossil fuel use reduction, increased potential for local and regional trade and economic self sufficiency, reduced reliance on expensive shore-side infrastructure and the potential for construction and maintenance of vessels in-country rather than importing old second-hand ships from outside the Pacific.

UN Secretary General Ban Ki-moon in his message to Transport Day, called for "new ways of moving goods and people. I have called a Climate Summit in September 2014 to raise political will and catalyze concrete action on all climate-related issues, including sustainable transport."7 The Secretary General commented that the $\$ 175$ billion voluntary commitment of the world's eight largest development banks at Rio+20 "has helped to make sustainable transport a significant feature of discussions on the post-2015 development agenda." Unfortunately, despite this level of support for immediate investment and the apparent signal that financing is now available for this sector, the signals from the actual agencies themselves are pessimistic. Since 2012 the authors of this paper have repeatedly approached all the agencies that were involved in financing renewable energy innovations for shipping in the Pacific including ADB, UNDP, ESCAP, and the EU. While all have been sympathetic, all have stated that it is not a priority area and all have declined to consider funding, either by grant or loan, for this sector.

Enhanced efficiency and renewable energy shipping is a "sunrise" industry internationally however recent initiatives into new technology solutions have focused on large-scale shipping. Numerous researchers are investigating improved vessel and engine design and the use of wind, solar, and biogas/bio-fuel systems for $10,000+$ ton vessels of all types. There is little work being done on the 10,000 ton and smaller vessels which service most of the developing world, shift $4 \%$ of global cargoes but contribute $26 \%$ of all shipping emissions or $\sim 1 \%$ of all global emissions (Gilpin, 2012). However, one vessel design by a Japanese not-for-profit organization, Greenheart Project, demonstrates the potential for cost and performance effective 100\% renewable energy freighters of $\sim 250$ ton for inter-island and inter-regional

\footnotetext{
${ }^{7}$ http://www.transport2020.org/newsitem/2164/message-from-un-secretarygeneral-ban-ki-moon-about-transport-day-2013 (Accessed 13 May 2014).
}

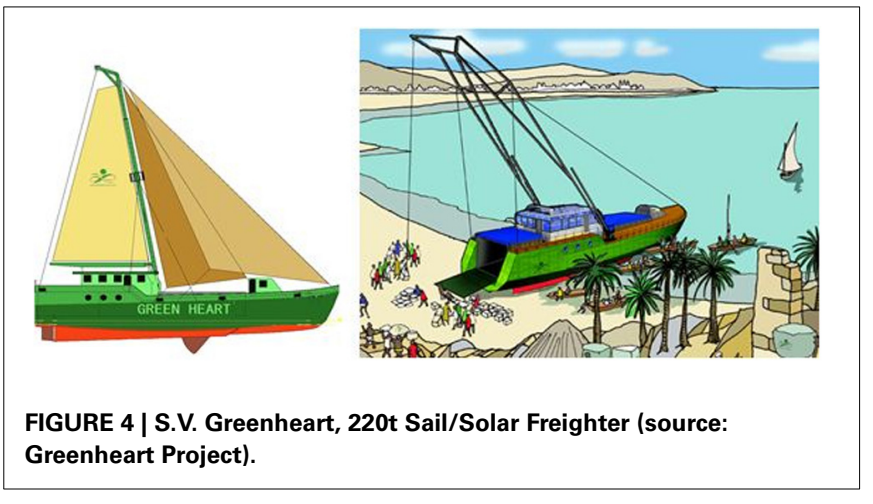

trade (see Figure 4). The Kwai, a sail-retrofitted small cargo ship serving the Rarotonga to Hawaii route, is reporting savings of up to $60 \%$ on fuel (Nuttall, 2013).

By way of example of the savings that are available we undertook preliminary modeling of the Rotuman route in 2011 which suggests the route's fuel footprint is approximately 800-900 tons of marine diesel oil (MDO) p.a. at up to US\$ 1000 per ton (Nuttall, 2013). The Fiji government currently subsidies $42 \%$ of the cost of a monthly shipping service. The $\mathrm{Na}$ Mataisau data showed an average 29\% saving for this route (Satchwell, 1985). Renewable energy alternatives could increase this by more than $50 \%$. Such savings would allow new ships to be purchased for around the cost of the existing subsidy and we suggest designs such as the Greenheart option would allow Fiji to demonstrate this technology at a domestic level to the rest of the Pacific. Looking inter-regionally, there are numerous export opportunities between Fiji and states like Tonga for increased trade in food products, timber, cement, garments, et cetera that are currently uneconomic due to the cost of container shipping which often requires transshipment through either Australia or New Zealand. Such inefficiency adds up to US\$100 per ton to the cost of export (SPC, 2011). Greenheart-type vessels are capable of servicing a direct link between Suva and Tonga, for example, on a fortnightly or monthly basis with potential for significant reductions in cost.

To this needs to be added a range of tertiary benefits. If small freighters can operate directly between village beach and markets there is automatically increased economic opportunity for farmers and small producers. Having vessels based in the communities of need rather than the major centers increases sustainable employment opportunities for such communities. Small-scale vessels capable of being fitted out, maintained, and ultimately constructed in-country offer potential to revitalize local shipbuilding industries that have been in serious decline since the 1980s.

\section{SHIPPING FINANCE}

This paper argues strongly for donor/agency intervention in trialing and backstopping renewable energy initiatives for Pacific sea transport. The corollary question to this, should the research demonstrate both need and solutions, is how introduction of such technological innovation is to be financed. The ADB 2007 shipping overview is typical of expert opinion that delivery of 
shipping service is best left to private investment and the market. Couper (1973) was also of this opinion when discussing the arrival of Ro-Ro domestic services for Fiji in the 1970s. Given the difficulties associated with maritime asset financing in the Pacific, the critical need of the service for Pacific communities, the disproportionate impact of failing to provide adequate services on the most remote and vulnerable communities and the entrenched pattern of old unsafe ships being replaced with old ships that is the norm under a private market model today, we suggest it is time for this assumption to be reviewed.

Sea transport is the Pacific's lifeline. It plays a critical role at all domestic and international levels. Given that the vast bulk of commodities and manufactured goods are transported by ship in the Pacific, and that much domestic travel is by sea, the cost, and quality of sea transport immediately affects the welfare of the poor as consumers and producers (AusAID, 2008).

The provision of safe and secure regional transport services is affected by numerous geographical, socio-economic, and technical factors including population mobility, susceptibility to natural disasters and other effects of climate change, national policies and regulations, and international instruments. Additional factors include appropriate vessel/craft operation and maintenance, route profitability, existing petroleum supply (quantity and quality), level of infrastructure, technical capacity, proximity of maintenance facilities, as well as mandatory safety and security auditing services (SPC, 2011).

The marginal nature of the industry has always meant that financing shipping investment, either for governments or private operators is difficult. The current global economic environment has only exacerbated this with industry advisors pointing to the finance market becoming increasingly cautious of such investments. Given the underlying economics of oversupply and the current day [freight] rates, the banks are more cautious. If they are going to put money into a project, it is on very particular terms. The long-held assumption that the private sector acting alone or unaided is best situated to provide services needs to be reexamined. Certainly there is a case for governments and agencies to play a role in providing access to vessel and industry financing through various mechanisms, potentially including providing loan security and preferred operator status for renewable energy powered or retrofitted vessels.

\section{CONCLUSIONS AND POLICY IMPLICATIONS}

This paper highlights the importance of focusing on sustainable sea transport in the Pacific. Just as Pacific people connected with each other using traditional sailing boats in the past, they could just as well increase their connectivity to enhance their economic and social well-being through efficient and sustainable shipping today. The lack of focus on maritime fuel use in the Pacific is a major omission from strategies to transition to low-carbon futures.

It is therefore argued that donors and agencies need to reconsider their strategies for the development of transport infrastructure in the Pacific. The drive to enhance regional cooperation and integration by the leaders of the Pacific over the last two decades has produced mixed results. The fact that PIC leaders and officials regularly meet and talk about the need to cooperate does not mean that they have the infrastructure for cooperation. Cooperation and regional integration will be better achieved when people, business, firms, and other enterprises are able to connect with each other. Many PICs find it difficult to connect with others in the region and also find that different islands in their own jurisdictions are not able to connect.

Finding solutions to the problem of inter-island connectivity could significantly improve the economic livelihoods of remote island communities. It would help enhance trade between islands and countries in a much better way than what we have now. The investment in renewable energy technology to reduce the region's chronic dependency of imported diesel for electricity generation that has happened over the past decade has resulted in an ad-hoc, disjointed and poorly monitored and evaluated program of work by multiple actors at various scales. It is only recently that a concerted effort has been made to try and rationalize this into an overall coordinated program. That transport generally and sea transport in particular has not thus far been addressed provides the region with the opportunity now to ensure that efforts to transition to a low-carbon pathway for transport starts from a coordinated, planned, and fully monitored footing. Achieving this is likely to be a challenge given the deeply embedded silo and "patch protection" modus operandi that characterizes the major donor and regional agency activity in the region. It also means rethinking the current flawed assumption that market forces alone are best placed to deliver affordable, adequate, safe, and environmentally sound transport solutions to the many, varied and far flung maritime communities that comprise the region.

A transition by PICs toward renewable energy and low carbon approaches in shipping is in fact consistent with and implements all global and regional sustainable transport policies. Just as we have argued elsewhere that there is little in the way of technology barriers stopping such transition occurring, there is also nothing in the policy framework resisting both donor agencies and the shipping industry to look closely into the matter.

\section{REFERENCES}

Asian Development Bank. (1985). Proceedings of Regional Conference on Sail-Motor Propulsion. Manila, Philippines. Asian Development Bank; 1985: 18-21 November. Manila: Asian Development Bank.

Asian Development Bank. (2007). Oceanic Voyagers: Shipping in the Pacific. Manila: Asian Development Bank.

Asian Development Bank. (2010a). Sustainable Transport Initiative Operational Plan. Mandaluyong: Asian Development Bank.

Asian Development Bank. (2010b). Responding to Climate Change in the Pacific: Moving from Strategy to Action. Mandaluyong: Asian Development Bank.

AusAID. (2008). 'O8 Pacific Economic Survey: Connecting the Region. Canberra, ACT: Pacific Affairs Group.

Brown, J. (1982). "New water working craft: special report," in The National Conference on Applications of Sail-Assisted Power Technology (Norfolk, VA).

Clayton, B. R. (1987). Wind Assisted Ship Propulsion. Phys. Technol. 18, 53-60 doi: 10.1088/0305-4624/18/2/301

Couper, A. D. (1973). "Islanders at sea: change and the maritime economies of the Pacific," in The Pacific in Transition: Geographical Perspectives on Adaption and Change, ed H. C. Brookfield (London: Edward Arnold), 229-247.

Couper, A. D. (2009). Sailors and Traders: A Maritime History of the Pacific Peoples. Honolulu, HI: University of Hawai'i Press.

Eyre, J. L., and Philp, C. E. (1982). General Purpose Sailing Vessel to Service Ha'apai Group. Suva: UNDAT. 
Food and Agriculture Organisation of the United Nations. (1987). "Artisanal fishing craft of the Pacific Islands," in Based on the Work of $\varnothing$. Gulbrandsen and M. Savins. RAS/87/002 (Suva: FAO/UNDP Regional Fishery Support Programme).

Gilpin, D. (2012). "Flagships of the future," in Presentation to the Sustainable Sea Transport Talanoa 2012 (Suva: The University of the South Pacific).

International Renewable Energy Agency. (2012). IRENA Policy Brief: Policy Challenges for Renewable Energy Deployment in Pacific Island Countries and Territories. Bonn: IRENA; United Arab Emirates.

Jafar, M. (2000). Renewable energy in the South Pacific - options and constraints. Renew. Energy 19, 305-309. doi: 10.1016/S0960-1481(99)00045-2

Kami, S., and Dillon, R. (1982). Intraisland Shipping in Ha'apai, Issues Relating to Private Boat Operations. Tonga: Central Planning Department.

Mayhew, J. (2011). "New Zealand aid programme - energy in the Pacific," in IRENA Workshop 26-28 October 2011, PowerPoint Presentation (Sydney). Retrieved 11 August 2013. Available online at: www.irena.org/DocumentDownloads/ events/Workshop_Accelerated_Renewable_Energy_Deployment/Session2/S2_ 7_Joseph_Mayhew_IRENA_energy_presentation_Oct_2011.pdf

Newell, A., and Bola, A. (in press). Solodamu: a survey of fuel and transport use in a coastal village on Kadavu, Fiji. J. Pacific Stud.

Nuttall, P. (2012). Steering a course for the future with sticks, stones, grass and a little sharkskin: the case for revitalisation of sail technology and sailing culture as a practical sea transport response to climate change and fossil fuel dependence/supply issues in Fiji. J. Pacific Stud. 32, 163-175.

Nuttall, P. (2013). Sailing for Sustainability: The Potential of Sail Technology as an Adaptation Tool for Oceania. Ph.D thesis, Wellington: Victoria University of Wellington.

Nuttall, P., Newell, A., Prasad, B., Veitayaki, J., and Holland, E. (2014). A review of sustainable sea transport for Oceania: providing context for renewable energy shipping for the Pacific. Mar. Policy. 43, 283-287. doi: 10.1016/j.marpol.2013.06.009

Palmer, C., and Corten, E. M. J. (1985). "Preliminary design study of Intraisland Transport Vessels for the Ha'apai Group of Islands in the Kingdom of Tonga," in Proceedings of Regional Conference on Sail-Motor Propulsion (Manila: Asian Development Bank). 133-170.

Prasad, B., Veitayaki, J., Holland, E., Nuttall, P., Newell, A., Bola, A., et al. (2013) Sustainable sea transport research programme: toward a research-based programme of investigation for oceania. J. Pacific Stud. 33, 78-94. Available online at: http://www.usp.ac.fj/index.php?id=16213

Rojon, I. (2013). Blowin' in the Wind? Possibilities of the International Maritime Organization to Promote the Uptake of Wind Propulsion in International Shipping. Master's Thesis. Utrecht: Utrecht University.

Satchwell, C. J. (1985). "Windship technology," in Proceedings of the International Symposium on Windship Technology (Windtech '85) (Southampton: University of Southampton).

Satchwell, C. J. (1986). "Preliminary analysis of log data from the Fiji windship Cagidonu," in Ship Science Reports, 24 (Southampton: University of Southampton).
Savins, M. (2012). "Pacific sail powered craft," in Successes and Failures and Lessons Learnt Presentation to the Sustainable Sea Transport Talanoa 2012 (Suva: The University of the South Pacific).

Secretariat for the Pacific Community. (2011). "Framework for action on transport services 2011-2020," in Improving the Efficiency, Effectiveness and Sustainability of Pacific Transport Services (Suva: Secretariat for the Pacific Community).

Secretariat for the Pacific Community. (2014). "Sustainable energy and transport services for all pacific island countries and territories," in Second Regional Meeting of the Pacific Ministers of Energy and Transport (Aviation and Maritime) Denerau Communiqué Nadi (Fiji). Available online at: http://www.spc.int/edd/en/document-download/finish/76-edd-reports/ 1375-denaraucommuniqueenglish

United Nations Economic and Social Commission for Asia and the Pacific. (1984). "Wind-powered vessels for coastal and inter-island use in the asian and pacific region," in Technical papers submitted to the Meeting of Experts on the Application of Windpower in Shipping Tokyo/Niigata 14-16 April (Tokyo: UNESCAP).

United Nations Economic and Social Commission for Asia and the Pacific. (2010). "Sustainable development in the pacific: progress and challenges," in Pacific Regional Report for the 5 year Review of the Mauritius Strategy for Further Implementation of the Barbados Programme of Action for Sustainable Development of SIDS (MSI+5) (Suva: UNESCAP Sub-Regional Office for the Pacific).

United Nations Economic and Social Commission for Asia and the Pacific. (2012). Growing Together: Economic Integration for an Inclusive and Sustainable AsiaPacific Century. Bangkok: United Nations.

USAid. (2010). Asia-Pacific Regional Climate Change Adaptation Assessment Final Report: Findings And Recommendations April 2010. Washington: International Resources Group.

Woodruff, A. (2007). The Potential for Renewable Energy to Promote Sustainable Development in Pacific Island Countries, SOPAC Miscellaneous Report 692. Suva; SOPAC.

Conflict of Interest Statement: The authors declare that the research was conducted in the absence of any commercial or financial relationships that could be construed as a potential conflict of interest.

Received: 15 May 2014; paper pending published: 10 June 2014; accepted: 21 June 2014; published online: 15 July 2014.

Citation: Nuttall PR, Newell A, Bola A, Kaitu'u J and Prasad B (2014) Policy and financing —why is sea transport currently invisible in the search for a low carbon future for Pacific Island Countries? Front. Mar. Sci. 1:20. doi: 10.3389/fmars.2014.00020

This article was submitted to Marine Affairs and Policy, a section of the journal Frontiers in Marine Science.

Copyright (c) 2014 Nuttall, Newell, Bola, Kaitu'u and Prasad. This is an openaccess article distributed under the terms of the Creative Commons Attribution License (CC BY). The use, distribution or reproduction in other forums is permitted, provided the original author(s) or licensor are credited and that the original publication in this journal is cited, in accordance with accepted academic practice. No use, distribution or reproduction is permitted which does not comply with these terms. 